\title{
Genetic diversity in local cultivars of garden pea (Pisum sativum L.) conserved on farm and in historical collections
}

Jenny Hagenblad, Erik Bostrom, Lena Nygards and Matti Leino

\author{
Linköping University Post Print
}

Tweet

N.B.: When citing this work, cite the original article.

The original publication is available at www.springerlink.com:

Jenny Hagenblad, Erik Bostrom, Lena Nygards and Matti Leino, Genetic diversity in local cultivars of garden pea (Pisum sativum L.) conserved on farm and in historical collections, 2014, Genetic Resources and Crop Evolution, (61), 2, 413-422.

http://dx.doi.org/10.1007/s10722-013-0046-5

Copyright: Springer Verlag (Germany)

http://www.springerlink.com/?MUD=MP

Postprint available at: Linköping University Electronic Press

http://urn.kb.se/resolve?urn=urn:nbn:se:liu:diva-105246 
Genetic diversity in local cultivars of garden pea (Pisum sativum L.) conserved 'on farm' and in historical collections

Jenny Hagenblad ${ }^{1,2}$, Erik Boström ${ }^{1}$, Lena Nygårds ${ }^{3}$ and Matti W Leino ${ }^{2,4}$

${ }^{1}$ Norwegian University of Science and Technology, Department of Biology, NO-7491

Trondheim, Norway

${ }^{2}$ Linköping University, IFM-Biology, SE-581 83 Linköping, Sweden

${ }^{3}$ Swedish University of Agricultural Sciences, Programme for Diversity of Cultivated Plants, PO Box 57, SE-230 53 Alnarp, Sweden

${ }^{4}$ Swedish Museum of Cultural History, SE-643 98 Julita, Sweden

Author for correspondence:

Matti Leino, Swedish Museum of Cultural History, SE-643 98 Julita, Sweden

Matti.Leino@nordiskamuseet.se 


\begin{abstract}
During a national Swedish collection mission of vegetable varieties conserved 'on farm' more than 70 pea accessions were obtained, many of which had been grown locally for more than 100 years. In spite of a likely origin in the multitude of obsolete commercial pea varieties available on the Swedish seed market in the $19^{\text {th }}$ century, the rediscovered local cultivars have lost their original names and cultivar identity while being maintained 'on farm'. To analyze genetic diversity in the repatriated material 20 accessions were genotyped with twelve SSR markers and compared with 15 obsolete cultivars kept in genebanks and 13 cultivars preserved as non-viable seeds collected in 1877-1918. Most of the local cultivars were genetically distinct from each other, and in only a few cases could a possible origin in a tested obsolete cultivar be suggested. These results reflect the wide diversity of pea cultivars present in Sweden during the $19^{\text {th }}$ century. Both between and within accession genetic diversity was larger among the historical samples of obsolete cultivars compared to local cultivars and cultivars preserved in genebanks, indicating genetic erosion over time both in genebanks and during conservation 'on farm'. The constraints on indentifying and verifying historical cultivars using genetic markers are discussed.
\end{abstract}

Keywords: cultivar identification, genetic differentiation, pea, Pisum sativum L., SSRs. 


\section{Introduction}

Peas (Pisum sativum L.) have a long cultivation history in the Fennoscandian countries Denmark, Finland, Norway and Sweden. From its centre of domestication in the Middle East (Zohary et al. 2012), peas were probably introduced in Fennoscandia at the same time as cereals, around 6000 BP (Hjelmqvist 1979). Peas are cultivated both in agriculture (field peas) and horticulture (garden peas) and are used for both for fodder and food, either grown to full maturity or eaten as a fresh vegetable. Historical records suggest that the biodiversity of peas cultivated in Sweden in the $19^{\text {th }}$ century was very large (Osvald 1959; Svensson 2004). The field peas grown were mostly landraces, i.e. genetically diverse and locally adapted, but lacking formal crop improvement (Camatcho-Villa et al. 2005). In contrast, garden peas were often commercial varieties, resulting from mass selections made in continental Europe or in Britain and marketed in large areas of Northern Europe (Osvald 1959). In a review of commercial seed catalogues from Sweden during the period 1850-1970 more than 200 varieties of garden pea were listed (Svensson 2004). The vast majority of these, however, disappeared from the market before the 1950s and can be considered historical or obsolete cultivars. Although many obsolete pea cultivars were preserved in genebanks such as the Nordic Genetic Resource Centre (NordGen) in Sweden and John Innes Centre in England, a large proportion of the obsolete cultivars seem to have been lost and become extinct.

In 2002 the Swedish national programme for plant genetic resources (POM) began to inventory and collect 'on farm'-preserved vegetable seed. At present, over 200 accessions have been gathered, and of these more than 70 accessions are peas (Nygårds and Leino 2013). Garden peas can be sub-classified according to a few significant characteristics: seeds being smooth or wrinkled and pods with (shelling peas) or without (edible podded) pod-wall sclerenchyma (Blixt 1977). The collected material consisted mostly of wrinkled shelling peas but other types were also found. The accessions that were assembled had been preserved in small home gardens as "family varieties" or "heirlooms" for 70 years or more. Most likely these varieties originated in the wealth of foreign cultivars marketed in Sweden during the $19^{\text {th }}$ and early $20^{\text {th }}$ century. However, the original identities, i.e. cultivar names, have unfortunately been lost over time. Instead the accessions have been given new names by the farmers, most often associated with the locality where the material had been maintained or an earlier curator of the heirloom. Because of their origin and history we will, in this article, call these accessions local cultivars. 
In a recent study of field pea landraces in Sweden high within and between accession genetic diversity was found, even though signs of genetic drift in 'on farm' preserved material was also indicated (Leino et al. 2013). Local cultivars of garden peas, however, differ from field pea landraces by having a cultivar origin, being maintained in small populations and with no regular seed exchange. The extent of genetic diversity, especially for European horticultural crops, preserved 'on farm' is largely unknown (Veteläinen et al. 2009). Thus, one objective of this study was to analyze the range of genetic diversity that could be found in local garden pea cultivars maintained 'on farm' in Sweden, a country with a highly industrialized agriculture.

We also aimed to genetically compare the newly collected material with obsolete cultivars with a known identity, to, if possible, identify the cultivar origin of the local cultivars. As genebank holdings only represent a small part of the cultivars present on the market in the $19^{\text {th }}$ and early $20^{\text {th }}$ century we complemented extant genebank accessions with historical seed material, stored at Swedish museums for a century and including historical cultivars not existing as extant material. The results show how 'on farm' preserved material reflects the large diversity of garden peas once cultivated.

\section{Materials \& methods}

\section{Materials}

Local cultivars were provided by the Nordic Genetic Resource Center (NordGen). These had been collected 'on farm' in Sweden during 2002-2004. Twenty accessions known to have been locally cultivated for more than 70 (and often more than 100) years were selected. Fifteen obsolete cultivars frequently marketed in Sweden during the late $19^{\text {th }}$ century (Svensson 2004) and preserved in genebanks were provided from NordGen (NGB) and John Innes Center (JIC), Norwich, UK. In addition, seeds of eleven accessions of obsolete cultivars not existing as extant material, but as historical specimens were analyzed. Most historical seeds were taken from the Royal Swedish Academy of Agriculture and Forestry (KSLA) seed collection stored at the Swedish Museum of Cultural History (NM) (Leino et al. 2009). These seeds have since harvest in the late $19^{\text {th }}$ or early $20^{\text {th }}$ century been stored in sealed glass containers at ambient temperature. They are thus non-viable, but do permit amplification of DNA markers by PCR (Leino et al. 2009). Additional historical seeds were provided by the Vänersborg museum. These seeds were displayed at an agricultural exhibition in Borås, 
Sweden in 1880 and have since been stored in sealed containers in room temperatures at Vänersborg museum (Johansson et al. 2003). Materials are summarized in table 1.

\section{DNA extraction and SSR analysis}

From each accession DNA was isolated from five individuals (four in the case of the accessions JIC662, NGB102773 and NGB17850). For extant material DNA was extracted from young leaves using the DNeasy Plant Mini Kit (Qiagen) or the E-Z 96 Plant DNA Kit

(Omega Biotek Inc., Norcross, GA, US). The DNA in historical seeds is of low quantity and fragmented due to DNA degradation. To avoid contamination from fresh material DNA extractions from historical seeds were performed in a separate laboratory. The DNA was isolated from the single dry seeds using the FastDNA® Spin Kit and the FastPrep® Instrument (Qbiogene, Inc., CA, US), where homogenization procedures are performed in sealed tubes to further avoid risks of sample-to-sample contaminations. DNA was eluted in $100 \mu 1$ of the supplied buffers. In each extraction series extraction blanks were performed in parallel.

SSR analysis was performed with twelve markers (Loridon et al. 2005) (Table 2). Markers were chosen to have a high polymorphic information content (PIC) value, be well distributed over the genome, and, to accommodate for the fragmented nature of the DNA in historical seeds, to amplify rather short fragments (less than $400 \mathrm{bp}$ ). PCRs were run as described in Leino et al. (2009). Amplification products were analysed by capillary gel electrophoresis and confocal laser scanning on a MegaBACE 500 DNA Analysis System (Amersham Biosciences) or an ABI 3130xl Genetic Analyzer (Applied Biosystems, CA, US). Some individuals were run on both systems for all markers to allow for comparisons of the results from the two systems. Sizing of fragments was performed using the software MegaBACE Fragment Profiler 1.2. or GeneMapper version 4.0. The scoring of the individuals genotyped on both systems were compared to ensure that results from both systems were fully comparable and could be combined for further analyses.

\section{Data analysis}

Wright's FST (1951) and Nei's h were estimated according to Nei (1973) using purpose-

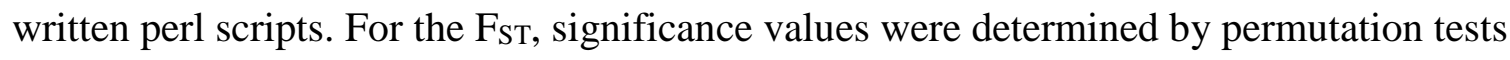
(1000 permutations). Principal component analysis (PCA) was carried out with the software R (R Development Core Team, 2007) using the prcomp command. In the PCA, data were 
analysed on an accession level where allele frequencies for each allele at each locus were calculated for the accessions analysed and treated as independent variables in the analysis. One-tailed, unpaired Student's t-test and calculation of correlation coefficient were carried out using the T.TEST and CORREL functions in Microsoft Excel (v 14.3.6).

The software Structure v 2.2 (Pritchard et al. 2000; Falush et al. 2003) was used to analyze the results for Bayesian clustering of accessions. As peas were largely or completely homozygous we used a haploid setting, exchanging the few heterozygous loci with missing data. We further used a model with correlated allele frequencies among populations with no admixture. Non-amplifying markers were treated as missing data. The software was run with a burn-in length of 20000 iterations followed by 50000 iterations for estimating the parameters. This was repeated ten times for each $\mathrm{K}$ (the number of predetermined clusters) until the likelihood values for the runs no longer improved. The software CLUMPP v 1.1.1 (Jakobsson and Rosenberg 2007) was used to compare the results of individual runs and to calculate similarity coefficients and the average matrix of ancestry. In CLUMPP the FullSearch algorithm was used for comparing runs with $\mathrm{K}<4$, whereas the Greedy algorithm was used for higher Ks. The number of clusters observed in the dataset was also evaluated by calculating $\Delta K$ according to Evanno et al. (2005). Graphical representation of the results was obtained using the DISTRUCT software v 1.1 (Rosenberg 2004).

\section{Results}

We used twelve highly polymorphic SSR markers to perform DNA genotyping of five individuals in each accession studying three sets of materials: 1) newly collected local cultivars, 2) extant obsolete cultivars from genebank holdings and 3) obsolete cultivars available as historical specimens. Most markers amplified successfully in most individuals showing low presence of null alleles and sufficient preservation of DNA quality in the historical samples. In seven (three extant and four historical) out of the 237 analyzed individuals a quarter or more of the markers failed to amplify. One of the individuals of the historical accession NM1294 failed to amplify in more than half of the markers and this individual was subsequently removed from all further analysis. Failed amplification was more common in the historical samples than in the extant material $(6.3 \%$ and $4.1 \%$ of all loci respectively, ttest, $\mathrm{p}<0.05)$. 


\section{Genetic diversity}

Within-accession genetic diversity across loci, $h$, ranged from 0.053 in the local cultivar NGB17846 to 0.475 in the historical accession NM1836 (table 1) with an average genetic diversity of 0.194 (s.d. 0.101, median 0.156). Locus specific genetic diversity across all individuals studied ranged from 0.283 for AD83 to 0.833 for B14 (table 2).

Although no accession was completely monomorphic, looking at each locus and accession separately more than half of the loci were invariable within a given accession. This meant that the total number of alleles across loci for each accession, ranging from 14 across the loci of JIC36 to 33 across the loci of NM1836 (table 1), was strongly correlated (c=0.913) with the genetic diversity of the accessions.

The historical accessions generally had higher within-accession genetic diversity than both the local cultivars (average 0.340 and 0.148 for historical accessions and local cultivars respectively, t-test $\mathrm{p}<0.001$ ) and the genebank preserved cultivars (average 0.146 for genebank cultivars, $t$-test $\mathrm{p}<0.001)$. The genetic diversity of the local cultivars and the genebank preserved cultivars were, however, of the same magnitude ( $\mathrm{t}$-test, $\mathrm{p}=0.471$ ).

\section{Genetic relationship}

To analyze the genetic relatedness of accessions, pairwise $\mathrm{F}_{\mathrm{ST}}$ values between all accessions were calculated (figure 1, table S1). Values ranged from 0.114 between the accessions NM1548 and NGB17829 to 0.873 between the accessions NM2462 and JIC36 with an average of 0.522 (s.d. 0.154 ). Of the 1035 pairwise comparisons performed only 31 were nonsignificant (figure 1). Of these 25 were between pairs of shelling, wrinkled peas and five between pairs of shelling, smooth peas while the remaining five non-significant comparisons were between peas of different types.

The proportion of alleles shared between pairs of accessions ranged from no alleles between NM1293 and JIC36 to almost $90 \%$ of the alleles between the local cultivars NGB17851 and NGB17854 (figure 1, table S1). While no pairs of accessions shared all alleles for all loci 2.5 $\%$ of the accession pairs shared $75 \%$ or more of their alleles. All of these were pairs of local cultivars. 
No accession had more than two private alleles, that is alleles not found in any other accession, across all loci (table 1). Seven accessions (two local cultivars, three extant commercial varieties and two historical varieties) and had two private alleles and another 16 accessions (six local cultivars, five extant commercial varieties and five historical varieties) had a single private allele. The remaining accessions shared all their alleles with at least one more accession.

Comparing accessions pairwise, the average number of shared alleles was 0.358 (s.d. 0.165). If the local cultivars are indeed descendants of any of the obsolete cultivars they should share a high proportion of alleles with that cultivar. Using $75 \%$ shared alleles as an arbitrary cut-off to identify the most similar pairs of accessions there were eleven instances where a local cultivar and a commercial variety had high allele sharing, three involving the accession NM1548, four involving NGB102775 and one involving NGB102773 (figure 1, table S1). Some local cultivars (NGB17834, NGB17828 and NGB17835) had, however, high allele sharing with more than one commercial variety (figure 1, table S1).

To visually describe the genetic similarities of different accessions we plotted the first two principal components of a PCA of the genetic diversity of the accessions (figure 2). PC1 and PC2 together explained only $15 \%$ of the total genetic variation, but separated a group consisting almost exclusively of shelling, wrinkled peas from two other groups consisting of a mixture of pea types. Pairs of accessions in this shelling wrinkled group made up the majority of the non-significant FST values (24 out of 31) and all but one of the pairs of accessions with more than $75 \%$ of their alleles shared between them further showing the genetic homogeneity of this group. Neither of the different types of pea examined (shelling, wrinkled; shelling, smooth; edible podded; snap pea) clustered in a unique type group in the PCA. Instead accessions of the same type tended to fall in different groups.

The pattern observed in the PCA was mirrored in a Structure analysis of the accessions (figure 3). $\Delta \mathrm{K}$ values and the $\mathrm{h}$ values obtained in CLUMPP both indicated that a clustering with $\mathrm{K}=$ 2 might best describe the data with some support also for a clustering with $\mathrm{K}=8$ (data not shown). At $\mathrm{K}=2$ the accessions clustered in two groups consistent with PCA along PC1 (figure 2, figure 3), one of which corresponded to the primarily shelling wrinkled group observed in the PCA but with the addition of the shelling wrinkled accessions NGB17841 and NGB17850. As in the PCA there was no consistent clustering of peas of the same subtype, 
neither at $\mathrm{K}=2$ nor at $\mathrm{K}=8$. Peas belonging to both groups were found among all three material types: historical, genebank maintained and local cultivar accessions. Peas clustering in the first group were, however, more common among the local cultivars than among the genebank maintained and historical accessions.

\section{Discussion}

The recent inventory of 'on farm' preserved local cultivars of vegetables in Sweden resulted in surprisingly many accessions repatriated. Home gardens were indeed recently suggested as hotspots for agro-biodiversity (Galluzzi et al. 2010). In countries with highly industrialized agriculture, such as Sweden, landraces grown on field scale are rare, and home gardeners are thus alternate guardians of crop biodiversity. We show here that local pea cultivars, maintained on a home garden scale, harbour genetic diversity not always covered by genebank collections. Interestingly, the accessions are mainly unique and genetically distinguishable from each other, suggesting that further search for local cultivars could result in more novel germplasm to be gathered.

In comparison with recently investigated Swedish field pea landraces (Leino et al. 2013), less genetic diversity is found among the garden peas (two-tailed t-test, $\mathrm{p}<0.01$ ). The higher diversity of field pea is to be expected as they have typically been propagated in much larger population sizes than garden peas and also have a landrace, rather than cultivar, origin. The differences in population size and origin between field pea and garden pea were also reflected in the within accession genetic diversity which was significantly lower in garden pea than in field pea (0.193 vs 0.353 respectively, t-test, $\mathrm{p}<0.001)$.

The garden peas were, in spite of population size and origin, not completely genetically invariant showing that propagation has been through progeny batches rather than single seed or single individual descent. That this has been the case was confirmed by the seed donors who reported using pods from several individuals for seeding the next generation. The historical samples of obsolete cultivars had higher genetic diversity than both genebank maintained cultivars and local cultivars. Although the same cultivars were not compared, these results suggest that many obsolete cultivars were originally more diverse, but have become genetically eroded over time. The risk of losing within-accession diversity during genebank maintenance of peas has been reported previously (Cieslarová et al. 2010; Hagenblad et al. 2012; Leino et al. 2013). However, this study also suggests that 'on farm' 
conservation of the cultivars succeeded no better in maintaining high within-variety diversity than genebank conservation.

PCA and Structure analysis showed that peas of a given type were not genetically distinguishable from all other types of peas. Instead clusters of genetically similar peas contained accessions of two or more different types. Traits defining pea types, such as smooth versus wrinkled seeds and presence/absence of pod-wall sclerenchyma are controlled by single loci (Blixt 1977), and can easily be crossed into a different genetic background. It is clear that already in the commercial pea varieties available in the $19^{\text {th }}$ century, alleles for the traits used for type classification occurred in a variety of genetic backgrounds, either from crosses between types or through recurrent mutation. Many of the local cultivars were genetically similar, but local cultivars comprised the whole range of the genetic diversity found (figure 2).

Comparing the local cultivars with obsolete commercial varieties we found no cases where pairs of accessions were genetically identical. Given that neither of the accessions were monomorphic this should not be surprising as genetic drift even in the absence of selection and mutation, which cannot be ruled out, will lead to differentiation. A questionnaire to the donors of the local cultivars showed that most cultivars had been regenerated every year meaning 100 to 200 generations for drift to operate.

Regardless of the presence of genetic drift we expect accessions with a shared origin to exhibit more genetic similarity than accessions of differing origin. Accessions with a shared origin should have low pairwise F $_{\text {ST }}$ values (though not necessarily non significant), a high number of shared alleles and few alleles present in only one accession. None of our local cultivars fulfilled all these requirements when compared to the commercial varieties, but many of the local cultivars (NGB17828, NGB17829, NGB17834, NGB17835, NGB17840, NGB17845, NGB17854 and NGB17858) had low $\mathrm{F}_{\mathrm{ST}}$-values and a high number of shared alleles when compared with the historical seeds of the commercial variety NM1548, 'Non plus ultra'. Several of the local cultivars (NGB17828, NGB17829, NGB17839, NGB17843

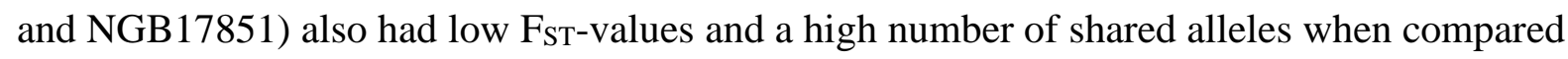
to NGB102775, 'Stensärt' and NGB17842 showed the same similarity when compared to NGB102773, 'Kelvedon Wonder'. These three cultivars ('Non plus ultra', 'Stensärt' and 'Kelvedon Wonder') where all marketed under a long time period and by many seed 
companies (Svensson 2004). Likely, at least some of the local cultivars originate from these historical cultivars, although they are not genetically identical. Noteworthy, several of the local cultivars were also by the seed donors named as "stensärt", beside their local names. 'Stensärt' is said to have originated in Sweden in the 1890s as a local selection of a foreign cultivar and was marketed on a large scale (Nygårds and Leino 2013).

The difficulty of finding additional matches of local cultivars with obsolete cultivars with known identity reflects the vast cultivar diversity once present on the seed market. The likelihood that our sample of commercial cultivars would include the origin to the local cultivar tested here is low. Our study also stresses the problems by proving authenticity of seed accessions as old cultivars by comparisons with material from herbaria or genebanks. Previous attempts in rice (Kobayashi et al. 2006), beets (Poulsen et al. 2007) and lettuce (van de Wouw et al. 2011) have proved difficult. If the old cultivars originally are heterogenous, as shown here, the forces of drift and selection will alter the genetic diversity over time. In addition crossing, seed mixing and mutations can also occur.

Even in the absence of a cultivar identity the repatriated local cultivars can serve as an important source of genetic variation and several of the studied local cultivars showed a high proportion of novel alleles not detected in the extant genebank accessions. $25 \%$ or more of the alleles detected in the local cultivars NGB17856, NGB17851, NGB17858, NGB17837 and NGB17833 were not detected in any of the genebank accessions. In addition the local cultivars NGB17833, NGB17838, NGB17846 and NGB17856 had high FST values compared to all other accessions (average $\mathrm{F}_{\mathrm{ST}}>0.6$ ), in particular when compared to the extant accessions (average $\mathrm{F}_{\mathrm{ST}}>0.67$ for all except NBG17856) highlighting these as particularly interesting for replenishing genebank genetic diversity.

The remaining newly collected local cultivars not investigated in this study will likely harbour additional genetic variation. Our data further suggest that local cultivars of garden crops are surprisingly often unique and not only duplicates. Thus, continuous efforts to sample plant genetic resources from home gardens would result in more variation possible to exploit in breeding. Gathering of crop biodiversity is often associated with landraces cultivated in areas with non-industrialized agriculture. This study shows the importance of inventorying local cultivars conserved in home gardens also in countries with a highly developed agriculture. 


\section{Acknowledgements}

We thank Svein Solberg and Fredrik Ottosson at the Nordic Genetic Resource Centre (NordGen), Alnarp, Sweden; Mike Ambrose at John Innes Centre, Norwich, UK and AnnCharlotte Öberg at Vänersborgs museum, Vänersborg, Sweden for kindly providing the seed material. This work was funded by the Lagersberg foundation, the Swedish Board of Agriculture and the Royal Swedish Academy of Agriculture and Forestry (KSLA).

\section{References}

Blixt S (1977) The gene symbols of Pisum. Pisum Genetics Newsletter 9: Supplement.

Camacho-Villa TC, Maxted N, Scholten M, Ford-Lloyd B (2005). Defining and identifying crop landraces. Plant Gen Res 3: 373-84

Cieslarová J, Smýkal P, Dočkalová Z, Hanáček P, Procházka S, Hýbl M, et al. (2010). Molecular evidence of genetic diversity changes in pea (Pisum sativum L.) germplasm after long-term maintenance. Genet Resour Crop Evol 58:439-451

Evanno G, Regnaut S, Goudet J (2005) Detecting the number of clusters of individuals using the software STRUCTURE: a simulation study. Mol Ecol 14:2611-2620

Falush D, Stephens M, Pritchard JK (2003) Inference of population structure using multilocus genotype data: linked loci and correlated allele frequencies. Genetics 164:15671587

Galluzzi G, Eyzaguirre P, Negri V (2010). Home gardens: neglected hotspots of agrobiodiversity and cultural diversity Biodivers Conserv 19:3635-3654

Hagenblad J, Zie J, Leino MW (2012) Exploring the population genetics of genebank and historical landrace varieties. Genet Resour Crop Evol 59:1185-1199

Hjelmqvist H (1979). Beiträge zur Kenntnis der prähistorischen Nutzpflanzen in Schweden. Opera Bot 47:1-58

Jakobsson M, Rosenberg NA (2007) CLUMPP: a cluster matching and permutation 
program for dealing with label switching and multimodality in analysis of population structure. Bioinformatics 23:1801-1806

Johansson P, Aarsrud S, Öberg A-C (2003) Det underbara huset: Vänerborgs museum (The wonderful building: The Vänersborg Museum). Vänersborgs museums skriftserie, 1651-842X; 1

Kobayashi A, Ebana K, Fukuoka S, Nagamine T (2006) Microsatellite markers revealed the genetic diversity of an old Japanese rice landrace 'Echizen'. Genet Resour Crop Evol 53:499-506

Leino MW, Hagenblad J, Edqvist J, Karlsson Strese E-M (2009) DNA preservation and utility of a historic seed collection. Seed Sci Res 19:125-135

Leino MW, Boström E, Hagenblad J (2013) Twentieth-century changes in the genetic composition of Swedish field pea metapopulations. Heredity 110: 338-346

Loridon K, McPhee K, Morin J, Dubreuil P, Pilet-Nayel ML, Aubert G, Rameau C, Baranger A, Coyne C, Lejeune-Hènaut I, Burstin J (2005) Microsatellite marker polymorphism and mapping in pea (Pisum sativum L.). Theor Appl Genet 111:1022-1031

Nei M (1973) Analysis of gene diversity in subdivided populations. Proc Natl Acad Sci USA 70:3321-3323

Nygårds L, Leino MW (2013). Klint Karins kålrot och mor Kristins böna: om fröuppropets kulturarv (Klint Karin's swede and mother Kristin's bean: cultural heritage of the seed call). Swedish Univ Agric Sci. Alnarp

Osvald H (1959) Åkerns nyttoväxter (Agricultural utility plants). Stockholm

Poulsen G, Holten C, von Bothmer R (2007) AFLP similarities among Danish cultivars of fodder beet (Beta vulgaris L. subsp. vulgaris var. rapacea Koch) Genet Resour Crop Evol 54:1105-1115

Pritchard JK, Stephens M, Donnelly P (2000) Inference of population structure using multilocus genotype data. Genetics 155:945-959 
R Development Core Team (2007) R: A language and environment for statistical computing. R Foundation for Statistical Computing, Vienna, Austria. ISBN 3900051-07-0, URL. http://www.R-project.org

Rosenberg NA (2004) Distruct: a program for the graphical display of population structure. Mol Ecol Notes 4:137-138

Svensson K (2004) Trädgårdsärt och trädgårdsböna: kartläggning av de i Sverige marknadsförda sorterna 1850-1970 (Garden pea and garden bean: Inventory of varieties of the Swedish market between 1850-1970). Swedish Univ Agric Sci. Alnarp

van de Wouw M, van Treuren R, van Hintum T (2011) Authenticity of old cultivars in genebank collections: a case study on lettuce. Crop Sci 51:736-746

Veteläinen M, Negri V, Maxted N (2009) European landraces on-farm conservation, management and use. Bioversity Technical Bulletin No 15. Bioversity International, Rome

Wright S (1951) The genetical structure of populations. Ann Eugen 15: 323-354

Zohary D, Hopf M, Weiss E (2012) Domestication of plants in the Old World: the origin and spread of domesticated plants in south-west Asia, Europe, and the Mediterranean Basin. (4th ed.) Oxford: Oxford University Press 
Table 1. Plant material used in the experiments and their genetic diversity. Donor accession names are indicated for the local cultivars that were collected 'on farm' between 2002 and 2004. Accession abbreviations refers to NGB=accessions from the NordGen, JIC= accessions from John Innes Centre, NM=accessions from the KSLA historic seed collection at the Swedish Museum of Cultural History, VÄ=accessions from Vänerborg museum. For the historic material, seed age is indicated within parenthesis.

\begin{tabular}{|c|c|c|c|c|c|c|c|}
\hline Name & Acc nr & Cultivar status & Material type & Subtype & $\begin{array}{l}\text { Genetic } \\
\text { diversity (h) }\end{array}$ & $\begin{array}{l}\text { Total } \\
\text { alleles }\end{array}$ & $\begin{array}{l}\text { Private } \\
\text { alleles }\end{array}$ \\
\hline 'Saga' & NGB17828 & Local cultivar & Extant & Shelling, wrinkled & 0.109 & 16 & 0 \\
\hline 'Stina' & NGB17829 & Local cultivar & Extant & Shelling, wrinkled & 0.160 & 17 & 0 \\
\hline 'Farmor' & NGB17832 & Local cultivar & Extant & Shelling, smooth & 0.344 & 25 & 0 \\
\hline 'Boaryd' & NGB17833 & Local cultivar & Extant & Edible podded & 0.148 & 17 & 2 \\
\hline 'Bolum' & NGB17834 & Local cultivar & Extant & Shelling, smooth & 0.067 & 14 & 0 \\
\hline 'Mormor Hannas' & NGB17835 & Local cultivar & Extant & Shelling, wrinkled & 0.100 & 16 & 1 \\
\hline 'Svartbjörnsbyn' & NGB17837 & Local cultivar & Extant & Edible podded & 0.202 & 20 & 1 \\
\hline 'Pjätteryd' & NGB17838 & Local cultivar & Extant & Shelling, smooth & 0.111 & 16 & 0 \\
\hline 'Vallagården' & NGB17839 & Local cultivar & Extant & Shelling, wrinkled & 0.148 & 18 & 1 \\
\hline 'Nybyggerud' & NGB17840 & Local cultivar & Extant & Shelling, wrinkled & 0.175 & 17 & 1 \\
\hline 'Norrhult' & NGB17841 & Local cultivar & Extant & Shelling, wrinkled & 0.068 & 15 & 0 \\
\hline 'Edsås' & NGB17842 & Local cultivar & Extant & Shelling, wrinkled & 0.205 & 19 & 0 \\
\hline 'Nusnäsärt' & NGB17843 & Local cultivar & Extant & Shelling, wrinkled & 0.273 & 22 & 1 \\
\hline 'Finas fina' & NGB17845 & Local cultivar & Extant & Shelling, wrinkled & 0.130 & 17 & 0 \\
\hline 'Örshultsärt' & NGB17846 & Local cultivar & Extant & Shelling, wrinkled & 0.053 & 14 & 0 \\
\hline 'Beda' & NGB17850 & Local cultivar & Extant & Shelling, wrinkled & 0.100 & 15 & 0 \\
\hline 'Demans' & NGB17851 & Local cultivar & Extant & Shelling, wrinkled & 0.142 & 18 & 2 \\
\hline 'Alunda' & NGB17854 & Local cultivar & Extant & Shelling, wrinkled & 0.152 & 17 & 0 \\
\hline 'Hilda' & NGB17856 & Local cultivar & Extant & Edible podded & 0.105 & 16 & 0 \\
\hline 'Mors stora' & NGB17858 & Local cultivar & Extant & Shelling, wrinkled & 0.173 & 17 & 1 \\
\hline 'Emerald Gem' & JIC36 & Obsolete cultivar & Extant & Shelling, smooth & 0.080 & 14 & 0 \\
\hline 'Gradus' & JIC303 & Obsolete cultivar & Extant & Shelling, wrinkled & 0.105 & 16 & 0 \\
\hline 'American Wonder' & JIC318 & Obsolete cultivar & Extant & Shelling, wrinkled & 0.109 & 16 & 1 \\
\hline 'Rapid' & JIC662 & Obsolete cultivar & Extant & Shelling, smooth & 0.073 & 14 & 0 \\
\hline 'Express' & JIC669 & Obsolete cultivar & Extant & Shelling, smooth & 0.085 & 15 & 1 \\
\hline
\end{tabular}




\begin{tabular}{|c|c|c|c|c|c|c|c|}
\hline 'Champion of England' & JIC1144 & Obsolete cultivar & Extant & Shelling, wrinkled & 0.252 & 19 & 0 \\
\hline 'Henderson's first of all' & JIC2247 & Obsolete cultivar & Extant & Shelling, wrinkled & 0.235 & 20 & 2 \\
\hline 'Knight's marrow' & JIC2462 & Obsolete cultivar & Extant & Shelling, wrinkled & 0.080 & 15 & 1 \\
\hline 'Kungsärt' & NGB13148 & Obsolete cultivar & Extant & Snap pea & 0.147 & 16 & 0 \\
\hline 'Fenomen' & NGB101332 & Obsolete cultivar & Extant & Shelling, smooth & 0.262 & 21 & 0 \\
\hline 'Victoria' & NGB102201 & Obsolete cultivar & Extant & Shelling, smooth & 0.142 & 17 & 2 \\
\hline 'Buxbom de Grace' & NGB102765 & Obsolete cultivar & Extant & Edible podded & 0.090 & 15 & 0 \\
\hline 'Kelvedon Wonder' & NGB102773 & Obsolete cultivar & Extant & Shelling, wrinkled & 0.135 & 16 & 0 \\
\hline 'Stensärt' & NGB102775 & Obsolete cultivar & Extant & Shelling, wrinkled & 0.180 & 18 & 1 \\
\hline 'Prince Albert' & NGB103066 & Obsolete cultivar & Extant & Shelling, smooth & 0.223 & 19 & 1 \\
\hline 'Blågrön engelsk' & NM1293 & Obsolete cultivar & Historical (1896) & Shelling, smooth & 0.327 & 21 & 2 \\
\hline 'Tysk moss' & NM1294 & Obsolete cultivar & Historical (1896) & Shelling, smooth & 0.280 & 20 & 2 \\
\hline 'Fürst Bismarck' & NM1537 & Obsolete cultivar & Historical (1918) & Edible podded & 0.238 & 20 & 0 \\
\hline 'Fairbeards Nonpareil' & NM1541 & Obsolete cultivar & Historical (1918) & Shelling, wrinkled & 0.415 & 24 & 1 \\
\hline 'Non plus ultra' & NM1548 & Obsolete cultivar & Historical (1918) & Shelling, wrinkled & 0.300 & 23 & 0 \\
\hline 'Engelsk Sabel' & NM1551 & Obsolete cultivar & Historical (1918) & Edible podded & 0.427 & 26 & 0 \\
\hline 'Witham Wonder' & NM1555 & Obsolete cultivar & Historical (1918) & Shelling, wrinkled & 0.280 & 22 & 1 \\
\hline 'Golden Drop' & NM1836 & Obsolete cultivar & Historical (1865) & Shelling, smooth & 0.475 & 33 & 1 \\
\hline 'Daniel O’Rourkes' & NM2335 & Obsolete cultivar & Historical (1877) & Shelling, smooth & 0.384 & 28 & 0 \\
\hline 'Dicksons favourite' & VÄ188 & Obsolete cultivar & Historical (1880) & Shelling, smooth & 0.266 & 24 & 1 \\
\hline 'Laxtons prolific' & VÄ201 & Obsolete cultivar & Historical (1880) & Shelling, smooth & 0.348 & 27 & 2 \\
\hline
\end{tabular}


Table 2. Fragment sizes, chromosomal location and number of detected alleles for the SSR markers.

\begin{tabular}{lllll}
\hline SSR marker & Chromosome & $\begin{array}{l}\text { Fragment size } \\
(\mathrm{bp})\end{array}$ & $\begin{array}{l}\text { Number of } \\
\text { detected alleles }\end{array}$ & $\begin{array}{l}\text { Genetic } \\
\text { diversity }(\mathrm{h})\end{array}$ \\
\hline AD147 & 1 & $317-349$ & 13 & 0.813 \\
AD83 & 2 & $275-287$ & 5 & 0.295 \\
AB109 & 2 & $332-386$ & 14 & 0.814 \\
AB141 & 3 & $139-235$ & 14 & 0.481 \\
AD73 & 3 & $240-292$ & 15 & 0.800 \\
AA278 & 3 & $166-178$ & 5 & 0.334 \\
AC58 & 5 & $216-258$ & 11 & 0.742 \\
AB130 & 5 & $211-247$ & 13 & 0.673 \\
AB71 & 6 & $158-182$ & 13 & 0.805 \\
AA200 & 6 & $214-236$ & 7 & 0.642 \\
AB122 & 7 & $318-340$ & 12 & 0.738 \\
B14 & 7 & $474-490$ & 9 & 0.834 \\
\hline
\end{tabular}




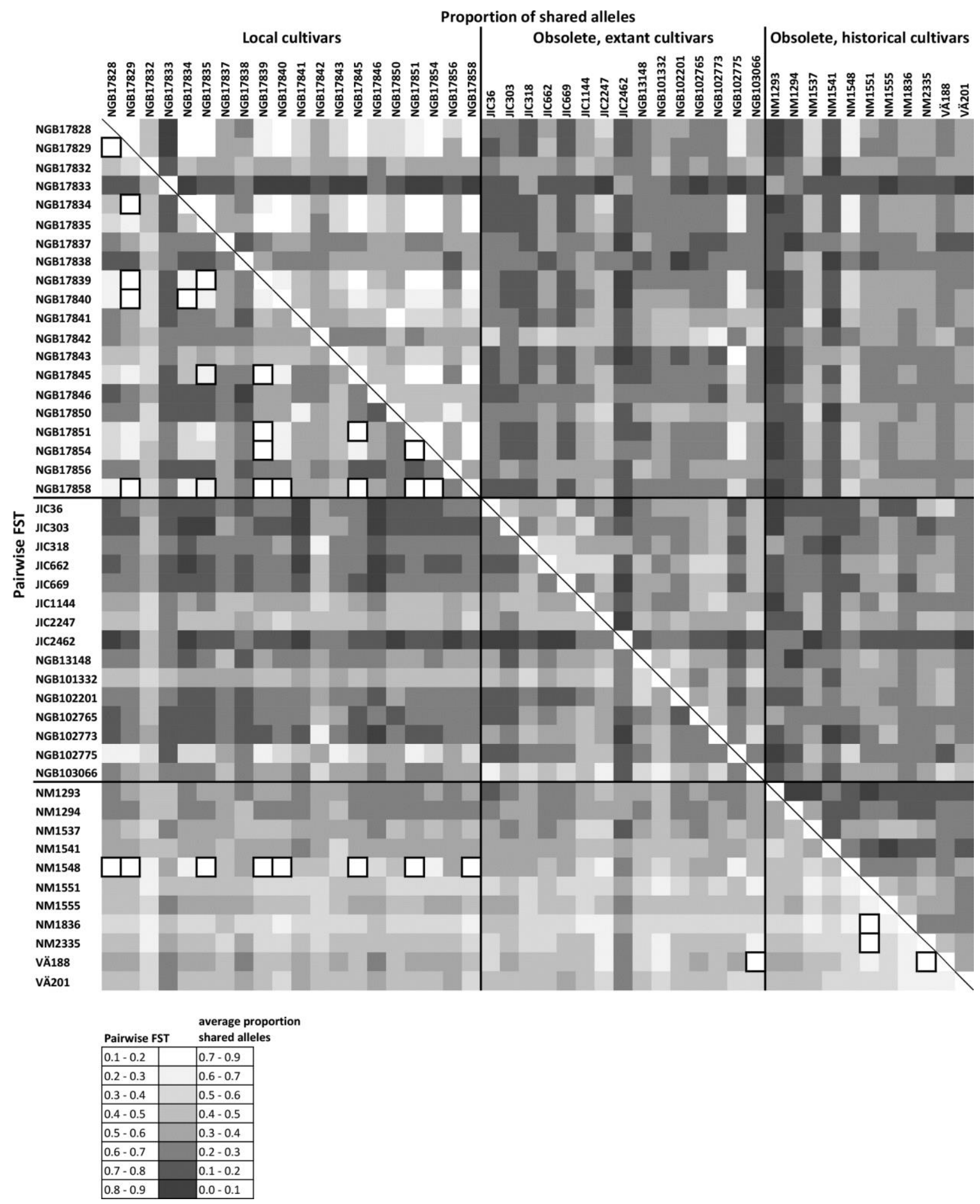

Figure 1. Genetic similarities between pairs of accessions. Pairwise $F_{S T}$ values are shown below the diagonal and proportion of shared alleles between pairs of populations above the diagonal. Darker colours indicate higher F $_{\text {ST }}$ values and lower average proportion of shared alleles. Cells with non-significant $F_{S T}$ values (all < 0.2) are marked with borders. 


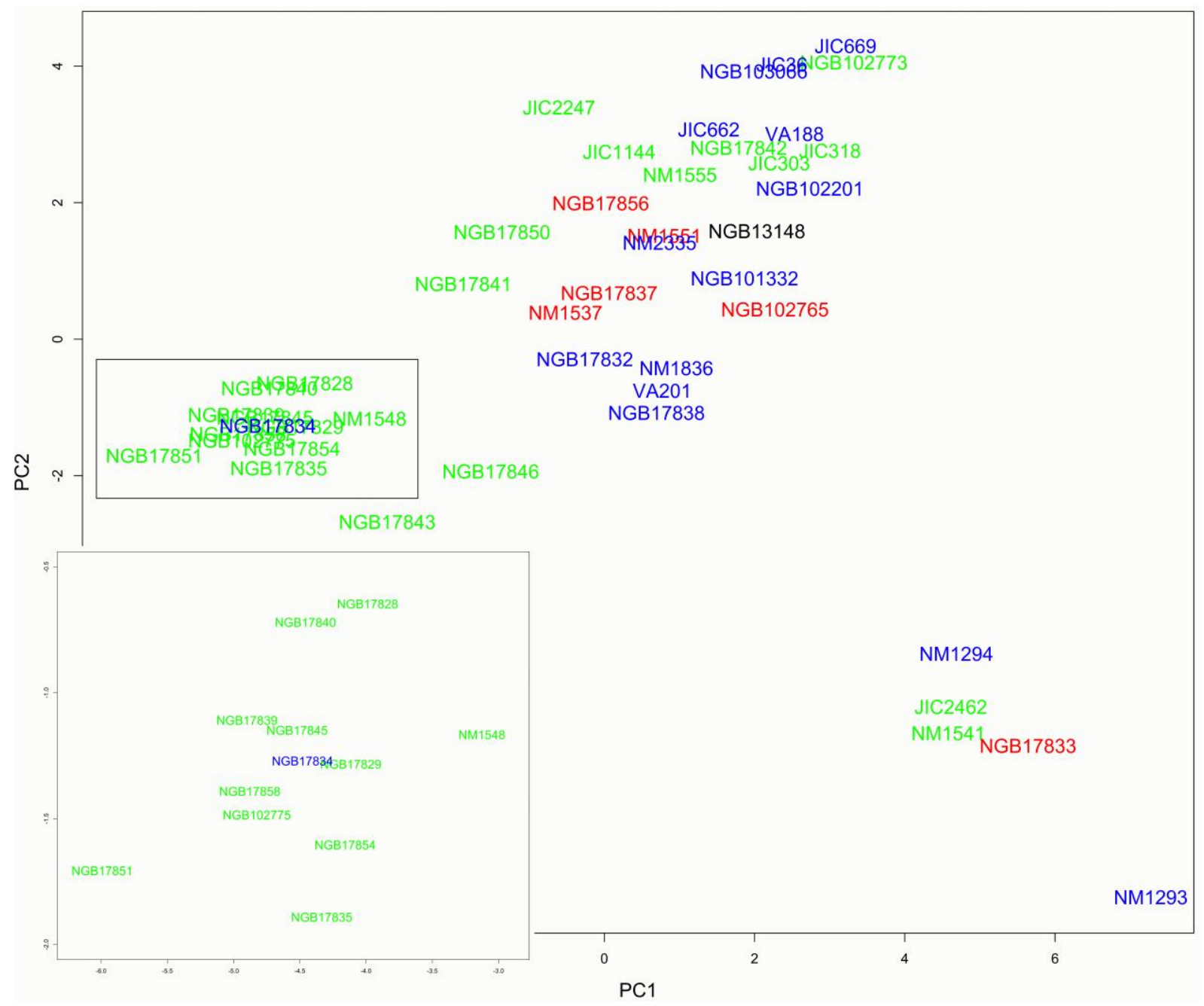

Figure 2. Associations between populations revealed by the first two PCs of PCA. Part of the biplot with many closely positioned accessions is magnified in the lower left corner. Colours denote different pea types: green $=$ shelling, wrinkled, blue $=$ shelling, smooth, red $=$ edible podded, black $=$ snap pea. 


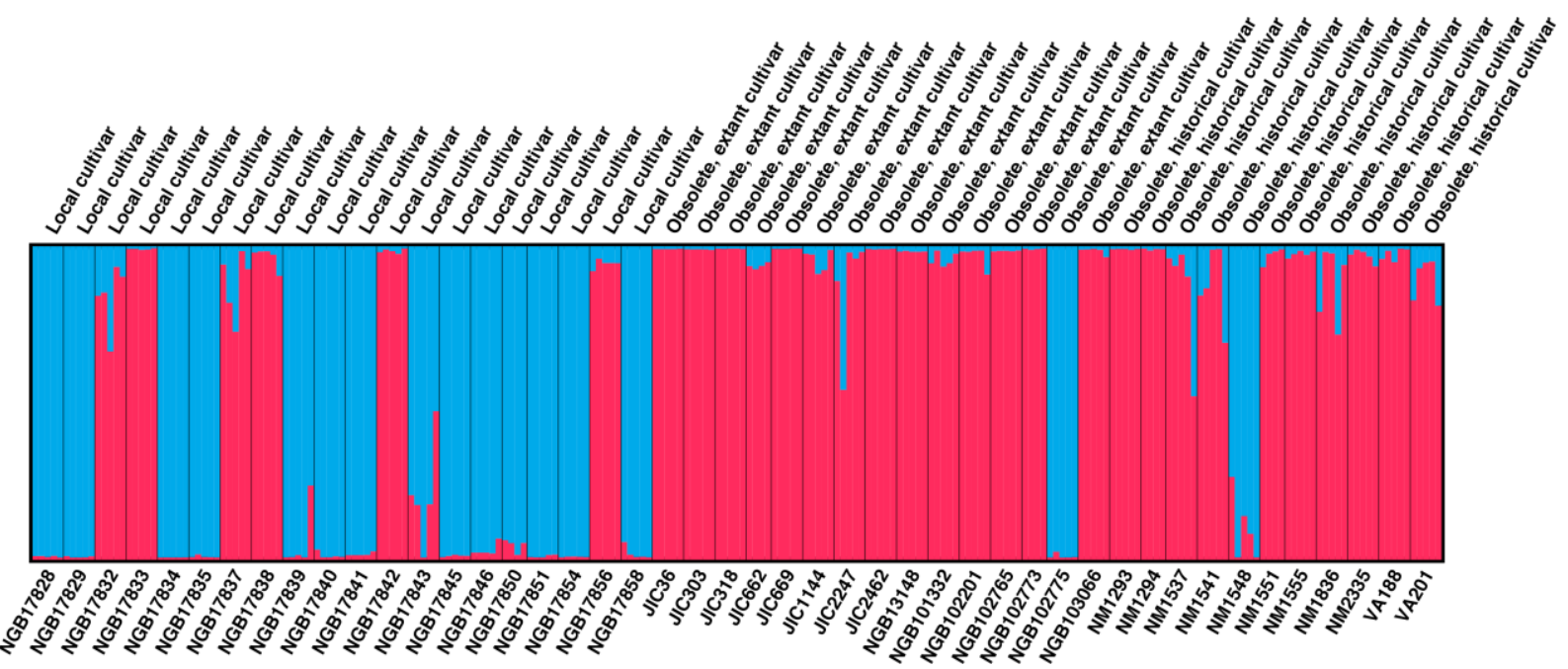

Figure 3. Barplot showing the assignment values of Bayesian clustering in the Structure analysis. Each vertical line corresponds to one individual where the colours denote the cluster or clusters that individuals belong to. Grouping for two clusters (blue or red) has strongest support (see text) and is shown here. 
Supplementary data

Table S1. Average proportion of shared alleles between pairs of accessions (above diagonal) and pairwise Fst values with significance levels (below diagonal)

(See supplementary file) 
